\title{
Breaking hospitality apart: bad hosts, bad guests, and the problem of sovereignty
}

\author{
ANDREW SHRYOCK University of Michigan
}

\begin{abstract}
Talk of hospitality often turns to the problem of bad guests and bad hosts. This trend holds whether the speakers are Balga Bedouin in Jordan or political theorists in Europe, and it would seem that bad hospitality accumulates in the gaps created by shifts in scale, as houses absorb other houses, or nation-states and their citizens compete to control the concepts and practices that define house, host, and guest. Moving from Bedouin history to metropolitan political theory, I show how bad hosts and guests break hospitality apart, revealing its component parts and how they work.
\end{abstract}

Like the Balga Bedouin, I am intrigued by bad guests, and I dread bad hosts. Whenever I encounter these characters - in Jordan, where they stand out and can be appreciated, not in the United States, where they are common - I immediately tell others about them, and seldom are people more eager to hear my news. I am not spreading idle gossip. I am keeping up local standards for excellence in the handling of guests and hosts. Among Bedouin, these standards are high, and Balgawis are always pleased to see that I understand them. Hospitality, karam in local dialect, is not simply a matter of offering tea, cigarettes, and pleasant conversation to guests. It is also a test of sovereignty. The man who is karim (hospitable, generous, noble) is able to feed others, project an honourable and enviable reputation, and protect guests from harm. Hospitality, as Bedouin describe it, is a quality of persons and households, of tribal and ethnic groups, and even of nation-states. At any of these levels of significance, failure to provide karam suggests low character and weakness, qualities that attract moral criticism.

In short, Bedouin assume that disputes over hospitality can open a social space to ridicule and ultimately to the threat of trespass and subordination. This negative potential makes bad hosts and bad guests important. It gives moral focus to the central problem of hospitality: namely how to enact autonomy and exchange, openness and closure, within the same social space. When Balgawis suggest that a nation-state can be hospitable, just as a person can, they acknowledge the scalar complexity that has made hospitality a concept of interest to metropolitan political theorists. The latter do not fixate on whether the tea was hot or the greetings ample, but they do share with 
Bedouin a concern for the status of outsiders in political spaces shaped by domestic privilege. This overlap is fascinating in its own right, and I have explored it elsewhere (Shryock 2004; 2008). What I would like to examine here is the tendency, prominent in Bedouin social thought and metropolitan political theory, to locate deficient hospitality in attempts to shift the scale on which domestic privilege is expressed: for instance, when one house incorporates another, when a nation-state is held accountable to the ethical demands that motivate its citizens as individual hosts and guests, or when citizens must be hospitable only in ways the nation-state allows. Why does bad hospitality accumulate along these fault-lines, and why is fault-finding so essential to hospitality discourses, wherever they are spoken?

\section{Shared and second language}

Balgawi notions of karam belong to a cultural complex that is geographically widespread and demonstrably ancient. It is a deeply ingrained ethnographic habit to suggest that Mediterranean and Middle Eastern societies are distinctive in their commitment to hospitality. Dismissing this trope as Orientalist is equally predictable, and I will resist the temptation. ${ }^{1}$ Instead, I would suggest that the obviousness of Arab hospitality as perceived by Occidental travellers, colonial officers, merchants, and, much later, ethnographers is evidence of overlapping sensibilities, not a taste for the exotic. The same could be said of Turkish hospitality, or Spanish, or Sicilian. As a zone of intersecting ethical traditions, the hospitality complex grows out of two foundational sources that were eventually brought together in regional scholarship. The first is the intellectual legacy of classical antiquity. Homer and Virgil composed epic poems devoted to the behaviour of bad hosts and wily guests; Greco-Roman mythology is replete with similar motifs, as gods and mortals penetrate each other's social worlds; and classical philosophy, from Socrates to Seneca, turns repeatedly to matters of generosity and the political status of strangers. ${ }^{2}$ The second legacy is Abrahamic. A peculiar set of moral expectations, often extreme and contradictory, accompanies hospitality in Jewish, Christian, and Muslim traditions, linking it to ideas that cannot be reduced to simple lessons in sharing and human kindness. These ideas surface in stories that evoke a sense of existential danger at the heart of social life: Lot offering his daughters to the licentious mob in Sodom to protect his guests; the Levite allowing his concubine to be raped to protect his host; Abraham offering his son as a human sacrifice, as one would offer an animal to guests or to God; and the motif, recurrent in the Qur'an, of a community that rejects its prophet, turning away from the divine revelation sent to it as gift and guest, thereby consigning itself to destruction. In all of these instances, hospitality is a test that can be failed; the stakes include life and death. ${ }^{3}$

When ethnologists first approached the problem of giving and receiving, they were attracted to the moral power expressed in these great traditions, and they used it to fashion their own brand of social critique. Mauss's classic, The gift, is transparent in its yearning for a cultural order in which hosts and guests take better care of each other. For all the attention Mauss gives to 'primitive' and 'archaic' societies, his famous 'Conclusions' chapter endorses an enlightened socialism based on barely modified versions of ethical values that have long dominated classical and Abrahamic thought: give to the weak, the poor, the aged; give to society, as if giving to God; feed the hungry; shelter the homeless. Indeed, Mauss seals his argument by quoting Qur'anic verses that enjoin charity. Urging a 'return to the old and the elemental', he invites us to 'discover those motives of action still remembered by many societies and classes: the joy of giving 
in public, the delight in generous artistic expenditure, the pleasure of hospitality in the public or private feast' (1967 [1925]: 67). If a Roman senator comes to mind, alongside the Winnebago chief, the image is hardly accidental.

Pitt-Rivers, whose work built productively on Mauss, was less romantic, but he was keen to bring together Abrahamic traditions and those of classical antiquity on the common analytical ground of hospitality, honour, and shame, terms that were prominent, and mutually defining, in the Mediterranean societies he studied. Pitt-Rivers is now seen as a regionalist, but his understanding of hospitality ranged widely in space and time. He saw affinities between the reception of strangers in Inuit villages, where recognition of the guest involved a ritual exchange of blows (Pitt-Rivers 1977), and the behaviour of buyers and sellers in English supermarkets, whose habitual mumblings of 'thank you' and 'you are welcome' are rooted in patterns of human interaction much older than the cash and credit exchanged alongside these polite formulas (Pitt-Rivers 1992). On display across these variable cases is a principle Pitt-Rivers identified as 'grace'. Like Mauss's gift, it is not reducible to calculation. Comparing it to hospitality, Pitt-Rivers described grace as 'something over and above what is due, economically, legally, or morally; it is neither foreseeable, predictable by reasoning, nor subject to guarantee. It ... can only be exchanged against its own kind' (1992: 239). The good host is graceful; the bad guest is an ingrate. These simple insights underlay the rules and improvisations that Pitt-Rivers explored in 'The law of hospitality' (1977: 94-112), an essay that ends with a lengthy deliberation on bad hosts and guests.

For ethnographers interested in cultural comparison, the telling feature of canonical research on hospitality is the ease with which its practitioners move from local to transregional frames of analysis. Hospitality is a shared language of human interaction, a first link between Others, a medium of greeting and exchange. Its status as a first and shared language is enhanced by the fact that it is always a second language as well, one spoken to outsiders, newcomers, and total strangers. Recent fascination with hospitality in philosophical quarters builds on related aspects of sharing and human difference. The status of foreigners is central, for instance, to Derrida's reflections on 'unconditional hospitality', just as the 'law of universal hospitality' was central, over two centuries ago, to Kant's formula for 'perpetual peace' among nations. I will return to these ideas. What is worth emphasizing here is that hospitality, as a topic of debate and moral analysis, seems always to expand beyond itself, to encompass other times and cultural settings.

The target of nearly all Derrida's essays on hospitality is the status of Muslim immigrants in France, yet the critical power of hospitality, as he perceived it, lies ultimately in its status as an ideal that is realized not in the language of 'rights' that dominates modern political thought, but in a more basic idiom of the open house.

\footnotetext{
[A]bsolute hospitality requires that I open up my home and that I give not only to the foreigner (provided with a family name, with the social status of being a foreigner, etc.), but to the absolute, unknown, anonymous other, and that I give place to them, that I let them come, that I let them arrive, and take place in the place I offer them, without asking of them either reciprocity (entering into a pact) or even their names. The law of absolute hospitality commands a break with ... law or justice as rights. Just hospitality breaks with hospitality by right; not that it condemns or is opposed to it, and it can on the contrary set and maintain it in a perpetual progressive movement; but it is as strangely heterogeneous to it as justice is heterogeneous to the law to which it is yet so close, from which in truth it is indissociable (Derrida 2000 [1997]: 25, 27).
}

The allure of a morality beyond law pulls Derrida away from a technical consideration of immigrant rights towards the deeper logic of welcome that captivated Mauss and 
Pitt-Rivers. It explains the attention he gave, in Of hospitality (Derrida 2000 [1997]), to Plato and Sophocles, to Genesis and Judges, in a discussion that includes personal status law in colonial Algeria, the limits of French citizenship, and new surveillance technologies. The ideas brought together under the rubric of hospitality are diverse, yet they belong to a single tradition, one that allows a poststructuralist philosopher and a Balgawi shaykh to say things that sound very similar. Derrida's frequent allusion to accepting guests without asking their names has direct parallels in Arab customary law, and his tendency to use images of absolute welcome as tools for social critique is duplicated by Bedouin storytellers recounting the tribal world of their youth.

\footnotetext{
Wherever you found people, their tents were open. Wherever you came to people, there was a mattress, and coffee, and a spike fiddle, and poetry. Poetry was in every guest chamber. And mansaf [a dish of lamb or goat on a bed of rice]. And bread. And they would spread out mattresses for you, and you could spend the night with them, and in the morning you would eat breakfast, then they would say, 'Peace be with you'. Or they would say, 'Stay for dinner', and they would all gather around you, and make a great fuss, and sweat from their effort to please you, and fight for the honour of hosting you, and they would slaughter an animal for you. In the past, hospitality was like that. Today, there is no hospitality. Today, everything is business. We buy and sell everything, and there's no shame in it (Hajj Salih Slayman al-Uwaydi, pers. comm., June 2000).
}

What some would interpret as a moralizing tone, a distaste for calculated interaction, and a preference for what, by today's standards, seems exceptional or excessive is in fact the soul of this teaching tradition. It is a judgemental tradition, and I would like to explore the prominent role bad hosts and bad guests play in shaping it. I will begin in Jordan, shift focus to larger political landscapes, then return to the Balga. This movement from karam to 'universal hospitality', then back again, is enabled by the scalar elasticity of hospitality itself, which is always of a place but inherently transportable. Designed for travel and to receive the traveller, hospitality is a motif open to extension and endless analogy. Its critical potential is located precisely in this openness, to which the bad guest and bad host are existential threats.

\section{Stagecraft and assemblages ${ }^{4}$}

The contradictory emotions that hospitality creates - pride, desire, jealousy, fear, excitement - are rooted in the assessments that host and guest make of each other. 'The guest', Jordanians tell me, 'is prisoner of the host'. Visitors are treated well, but their mobility is limited. They cannot move freely about the house or help themselves to food and drink; they depend on their hosts for protection and respect. But guests eventually move on, leaving behind more proverbial wisdom: 'The host must fear the guest. When he sits [and shares your food], he is company. When he stands [and leaves your house], he is a poet'. Guests, in other words, will make your reputation or break it, so handle them with care. Treat them reverently. The art of hospitality among Jordanian Bedouin is akin to religion and can trump it. Hence, 'the generous man is beloved of God', even when he does not pray as often as he should. Hospitality also has the gravity and stigma of politics, but is more important. It is described as 'a kind of war', and this likeness is widely considered a corruption of hospitality's powers. Before I knew better, I told Jordanians that I was studying the politics of hospitality. 'True hospitality is not political', I was instructed. 'It is not calculated'. I was encouraged to concentrate my ethnographic attentions on 'true hospitality', the ideal - which existed in the past or in the desert - and to look away from almost any real version of karam I might observe or 
receive. This advice was hard to follow. Like any guest, I was a prisoner of my hosts. Unless I decided to be a bad guest, I could only see what they wanted to show me.

Stagecraft is essential to the management of this situation. In Jordan, as elsewhere, the pleasures and anxieties of hospitality are expressed architecturally, in interactional styles, and in the use and display of special objects: food, drink, utensils, décor. There is almost always, in Balgawi homes, a special space set aside for the entertainment of guests. Outsiders are received and fed there, and may even sleep there, but this space is not to be confused with the rest of the house, where the guest's food is prepared and the host's family go about their business. When a Jordanian says, 'My house is your house', he does not mean all of it. He means that part of it which forms the stage for hospitality. Here, everything is or becomes a prop. The material culture of hospitality is often showy, with guests receiving the best mattresses, the best cups, the best spices in the best teapot. As a family's economic means improve, the amount of capital they invest in their house's hospitality showrooms increases. The good teacups are augmented by kitsch displays of antique brass coffee pots, bean roasters, and grinding drums, not to mention decorative swords and rifles. Prominent men will sometimes build a diwan, a veritable hospitality suite adjacent to their house, so large numbers of guests can visit without ever bothering to enter the host's 'real' living space.

But even the poorest Bedouin, still living in a tent or a two-room cinderblock house, will be able to create the hospitable effect by means of language and a deft manipulation of space. The greetings extended to guests are elaborate, and the occasional repetition of ahlan wa sahlan (welcome) reminds everyone that they are interacting in a space of hospitality. The offering of even the most ordinary coffee, tea, and food has a choreography that sets the hospitality situation apart, filling it with thresholds that must be crossed in the right order, at the right pace. The potential for welcome and trespass is just as great here as it is in the lavish diwans of shaykhs. As long as there is a host, a guest, a space of performance and evaluation, and a backstage set apart from the guest, the most essential points in the hospitality assemblage are in place. In the oral traditions I have recorded from Balgawis, hospitality assemblages figure as means to establish the sovereignty of social groups of different sorts and sizes, ranging from families to villages, tribes, and states. The telling of oral history is a verbal re-enactment of this local political tradition. Certainly this was true in my case. I was told history as a guest first, a researcher second. Teaching me about the past was possible only if my hosts could create a sovereign space in which historical knowledge could be granted to me as a gift, along with food and drink.

Indeed, a Balgawi cannot make claims to sovereignty without constructing a house, literal and metaphorical. A house without guests, without the spaces necessary to take them in, and without the materials needed to prepare food and drink, is not only weak, it is shameful. This is widely understood. The schoolteacher builds a house with an appropriate sitting room and veranda; clan leaders build freestanding communal guest houses in which they entertain politicians or host dispute resolutions; the municipality pays for a giant, monumental coffee pot erected at the centre of town to assure outsiders that they are welcome; and the Hashemites have their royal diwan in Amman, and their palaces, where the choreography of reception is a distinctive blend of tribal hospitality protocols, taught to Abdullah I by local shaykhs and urban notables, the etiquette of the English royal court, taught to him by British colonial advisers, and the manners of the late Ottoman world, in which the dynasty was born. Scaling up and down within this system is constant, as royals visit tribal councils, well-dressed shaykhs 
bring petitions to government offices, and the king and queen are shown on national television receiving their guests of state. ${ }^{5}$

At all points along these scales, sovereignty is manifest in the ability to act as host, and this is why it makes sense to most Jordanians when the Hashemites describe Jordan as a house, and Jordanians as a family. Such rhetoric is a show of mastery. Whenever it is spoken, a space of hospitality is created in which hosts can honour their guests. Junior members of the household (in other words, all Jordanians except the king) must join in as loyal supporters or remain silent and out of the way. The history of modern Jordan is, in effect, the story of how the Hashemites successfully transformed a diverse array of tribal groups, villages, towns, and refugee populations into a political formation that can be meaningfully described (and contested) as the House of Jordan. Among Balgawis, the Hashemites represent a new consolidation of power in a long procession of ruling families, many of whom linger on, eclipsed and domesticated, as part of the Jordanian national elite. The rise and fall of these groups is often explained in stories of hospitality gone wrong. The role of hospitality is literal in these tales: entire political worlds collapse and rise in strategic encounters between guests and hosts, within the physical space of the guest chamber.

After hearing hundreds of these stories, I have seen that things are likely to go wrong when a shift in political scale is attempted, when a host tries to reduce his equals to the status of guests, or subordinates assert their status as hosts. These moments are rich in potential for disaster, largely because a claim to sovereignty is being made before a new house has been completely built, or a rival house has been completely demolished. The result is a disabling exposure of weakness, manifest in the inability to hold a hospitality assemblage together. House, host, guest, the utensils needed to dispense hospitality, and the people who provide the raw materials of karam (women, children, slaves, allies, and dependent labour) all fall out of alignment and become available for misuse or confiscation. The breakup of hospitality assemblages is how shifts in Balga political coalitions were accomplished in the past and how they are remembered (and predicted) today. The tension between hospitality as a kind of politics, and hospitality as a morality that transcends and governs the political, is essential to this interpretative tradition.

\section{Breaking and reassembling}

The history of the Adwan, one of the Balga's most powerful families, is a perfect example of this process. In the 1990s, I recorded Adwani oral histories from tribal elders known for their poetic and genealogical knowledge. I was also given access to the private archive of Muhammad Hamdan al-Adwan, a local historian who spent hours reading to me aloud from manuscript versions of oral traditions he had recorded from Adwani storytellers. Much of this material I have published elsewhere (Shryock 1997), giving special attention to the context and exact delivery of these traditions. Here, I would like to compress the material, showing how key points of transition in the growth of the Adwani shaykhdom are remembered as moments in which bad hosts and bad guests did essential political work. Seven episodes will suffice to establish the pattern:

1. In the seventeenth century, the first Adwanis, Fayiz and Fowzan, come to the Balga as refugees. Within hours of their arrival, they kill the slave of their host, the Mahfoud al-Sardi. The slave had tried to take their swords by force. Their host 
then tries to kill Fayiz and Fowzan, but he is forced to accept them into local society after they are offered sanctuary by one of his subordinate shaykhs.

2. By the second Adwani generation, Hamdan, son of Fayiz, has become a member of the entourage of the Amir al-Mihdawi, leader of the local confederation of tribes. Hamdan takes part in a raid of the annual Hajj caravan. His share of the loot includes a mangy, hobbled camel. It turns out that this camel is carrying the caravan's gold. Hamdan uses this gold to buy the loyalty of the Amir's men. His success is signalled by his refusal to visit the Amir and interact with him in the role of guest. This refusal triggers violence between his faction and that of the Amir.

3. Hamdan spends the rest of his life fighting the Amir. He dies in battle. His son, Adwan, continues the campaign. Meanwhile, the ageing Amir al-Mihdawi sees a beautiful Christian girl in a local town and insists on marrying her. The Christians ask Adwan for help. He advises them to invite the Amir and his men to an engagement feast, but to put no salt in the meal, and to loosen the saddles of their horses. The Christians do so, and Adwanis, who are hiding nearby, attack the Amir as he is about to eat, killing him and almost all his men.

4. Adwan and his sons succeed in displacing the Amir from the Balga, whereupon they assume control. The sons of Adwan begin to fight among themselves over the distribution of land. Some of them flee to a rival tribe, the Sardiyya, and are given refuge. Adwan goes to retrieve them, but the protectors of his sons take his visit as a chance to kill their old foe. As the Sardiyya women sing poems in his honour, Adwan's hosts slay him.

5. Adwan's son, Dhiyab, attacks the Sardiyya, killing dozens of their men. In response, the Sardiyya send three virgin girls to Dhiyab as a request for mercy. Instead of tying white ribbons to these most vulnerable of guests, then returning them to their families unharmed, Dhiyab threatens to marry them to his slaves. The slaves, horrified, ask Dhiyab's brother, Salih, to intervene on behalf of the girls. Dhiyab agrees to return the girls unharmed, but he and Salih are now at odds.

6. Dhiyab, a violent and erratic man, is not popular with the local tribes. He flees to the north, and his brother, Salih, occupies the local town of Salt, which he hopes to hold against Dhiyab. Having cut a deal with the Turks in Damascus, Dhiyab returns to unseat Salih. Meanwhile, Salih has antagonized the Salti clans. He will not share water with them, and they cannot entertain the visitors who stay in their guesthouses. They invite Salih to a feast, at which they murder him.

7. After Salih is killed, Dhiyab regains control of the Balga. He builds a fortress in Hesban, several miles from Salt, takes control of local water sources, and builds flour mills, so he can control the local distribution of grain. Like his brother, he antagonizes the people of Salt, who invite him to a feast. While he eats, they drop a millstone on his head.

After this series of events, which unfolded between AD 1670 and 1800, Hamood, son of Salih, became paramount shaykh of the Balga. Adwani dominance continued, with sporadic expulsions and defeats, for another century. In 1867, Ottoman forces invaded the Balga and took control of Salt. In local historical traditions, this event triggers relentless acts of bad faith between the Turks and the Adwan, who cannot accept each other as hosts or guests. Adwani shaykhs are betrayed and captured at feasts, after their 
safety has been guaranteed, and Turks are attacked when they visit Adwani camps to collect taxes. When the British and Hashemites arrived in the 1920s, the Adwan felt they were being undermined by the new powers, and they fomented a revolt. Trounced by the British, the Adwan made peace with the Hashemites - at a feast hosted by Abdullah's father, the Sharif Husayn - and settled into their new role as regional notables. According to stories still popular among the Adwan, the last great Adwani shaykh, Majid bin Sultan (d.1946), opposed the Amir Abdullah's desire to become a king. Majid shared his misgivings with Abdullah at a feast hosted by the Amir. Later that night, Majid died. Many people believe Abdullah poisoned him. ${ }^{6}$

This parade of hosts and guests behaving badly could be doubled in length. Moreover, a list of similar episodes could be produced for other Balga tribes, and examples could be drawn from the lower rungs of the local power structures, not simply from elite families. Why do bad hosts and bad guests play this crucial role in local historical accounts? There are several obvious reasons. Most importantly, these stories tell Balgawis what good hosts and guests are like. They are morality tales, and their popularity registers the ethical and political weight of the hospitality complex, which enshrines the house as an ideal social form, the host and guest as ideal political actors. The feast and the guest chamber are communal spaces, if not fully public ones, and they are meant to be stages. Apart from the battlefield, these were the principal sites at which the mastery of Adwani shaykhs could be expressed and challenged. Feasts were highly compressed events into which the powers of a hospitality assemblage were channelled, then redistributed among clients and allies, who made incessant claims on the wealth and muscle of Adwani shaykhs.

Breaking one of these assemblages apart was always a bid for supremacy, and the guest chamber, as a venue for war and peace, was the leverage point at which these deconstructive forces could have their greatest effect. At the feast, the assemblage is most completely revealed (strength, propriety, and wealth are conspicuously on display) and concealed (vulnerable nodes in the production of strength and wealth, tensions within the house, dependence on other houses, and zones of impropriety are conspicuously not on display). ${ }^{7}$ The representational power of this performance space can be seen in the unwillingness of shaykhs to opt out of giving and attending feasts, especially in times of political instability. Refusing to act as host would undo a house as surely as poisoned tea would kill a guest. Indeed, the likelihood of meeting bad guests and bad hosts increases the value of hospitality and enhances the prestige of those who survive these encounters.

What tales of hospitality gone wrong produce, ultimately, is clarity in a system that, to operate well, must not show all of its components at once. The breakup of the hospitality assemblage offers a rare glimpse of how it works and how it can be manipulated. When Adwani influence grows, it is the result of good fortune (a bag of gold), gaining control over new sources of wealth (monopolizing water sources), or mobilizing forces in opposition to injustices perpetrated by other prominent men (the Amir Mihdawi's attempt to force a marriage), all of which require or enable the practice of hospitality. No black-and-white morality governs the process. The Adwan offend their guests and hosts as often as they are victimized by them. When these offences occur, however, women, slaves, townspeople, and other subordinate actors become prominent in the historical narratives, suggesting their centrality to the giving and receiving of karam in ways that are ordinarily muted. Finally, preventing subalterns and rivals from providing karam (by denying them water, buying off their guests, banishing them, and 
controlling their access to grain) is a crucial feature of political contest. When a house is operating smoothly as a sovereign space, these elements of plot and political method disappear from view; keeping them invisible is a sign of power. The smoothly operating hospitality assemblage is also, paradoxically, a wellspring of resentment and intrusive demands for sharing, which Balgawis assume to be constant aspects of social life. Bad hosts and bad guests will eventually appear in every diwan. It is their duty to generate memorable events, keep us alert to the performance and assessment of moral virtues, and encourage the deliberate exercise of power over self and others.

\section{Analogies and extensions}

The unequal relationship between host and guest, an imbalance that can be expressed in abuse or caring, is the common ground on which Balgawi ideas of karam merge with those that Western political theorists now find so intriguing. Because hospitality is a shared language (I assume all my readers are familiar with houses, with hosts and guests, with welcome and trespass) and because hospitality is a second language (I assume you do not talk to guests or hosts in quite the way you do to members of your own household), it is easy to apply hospitality rhetoric to contemporary problems of human mobility. Activists engaged in the politics of immigration - the Sanctuary Movement, the Sans Papiers Movement, the Cities of Refuge Movement, the New Sanctuary Movement - rely heavily on hospitality motifs. The exile, the stranger, the migrant, the minority: all are terms easily assimilated to the category of 'guest'. Likewise, the nation, the state, the nation-state, the native-born, and the mainstream can be equated with the category of 'host'. Yet these scalar shifts, in which older notions of house and family collide with newer ideas of citizenship, produce morally disturbing results. Citizens should interact as equals, even when they are not; hosts and guests cannot interact as equals, even when they are. The results are familiar. Fellow citizens become bad hosts when they refuse to respect the difference of immigrants and new citizens; similarly, newcomers who aspire to become citizens, or at least to enjoy the rights of citizens, come across as bad guests when they refuse to respect the ways of the 'host society'.

In the United States, a country that takes pride in its history as a 'land of immigrants', the distinction between host and guest is politically charged and often offensive, since each role carries a moral advantage that cannot be recognized without calling the equality of citizens into question. Guests must be treated well and should even receive preferential treatment, but they are not expected to stay (as guests) nor are they really considered members of the host community. Consider the advice to immigrant activists offered by California Governor Arnold Schwarzenegger, himself an immigrant to the United States:

\footnotetext{
Being an immigrant is like being a guest in someone's house. Your hosts go about their daily routine. You can sit on the couch and do your own thing, or you can ask, 'What can I do to help? How can I be a part of this household?' What people see today when immigrant rights activists march in the streets carrying Mexican flags and angry signs is that you do not want to join America's house. The message that sends is that you do not want to learn our language or our culture. Unlike the message sent by the masses of Irish, Italian, German and Asian immigrants, whom Americans now proudly call our 'melting pot,' these images suggest that Mexican immigrants do not want to make that effort (Los Angeles Times, 12 September 2006).
}

Schwarzenegger is a creature of the American political right, but his use of hospitality motifs is vexed by ambiguities that extend to the political left, in the United States and 
in much of Europe. Note how, in Schwarzenegger's nation-as-house motif, neither guests nor hosts can persist in their roles over time. Both roles are treated as obstacles to identification. Derrida (1997), offering advice to the political left, used the same hospitality motifs to intensify this untenable situation and play with its contradictions. 'I should try to open my space', he argued, 'without trying to include the Other in my space', without insisting that the Other 'learn my language, or adopt my religion or become English or become French'.

[That's] the prevailing left-wing discourse, "we are hospitable to the immigrants to the extent that they become French citizens, respect secularism, that they learn the French language," assimilation. We call this integration ... But that's a double bind, on the one hand I should respect the singularity of the Other and not ask him or her that he respect or keep intact my own space or my own culture ... [but on the other] ... I have to accept if I offer unconditional hospitality that the Other may ruin my own space or impose his or her own culture or his or her own language. That's the problem: hospitality should be neither assimilation, acculturation, nor simply the occupation of my space by the Other. That's why it has to be negotiated at every instant, and the decision for hospitality, the best rule for this negotiation, has to be invented at every second with all the risks involved, and it is very risky. Hospitality, and hospitality is a very general name for all our relations to the Other, has to be re-invented at every second, it is something without a pre-given rule.

In its spontaneous, highly negotiated forms, hospitality disrupts the fictions of legal equality, of national sameness, on which so much of contemporary political society is based. The guest Derrida describes can only be a foreigner (but one who should enjoy open access to 'my space'), and the space of hospitality, insofar as it is truly open to outsiders, cannot be bounded or sovereign in exclusive ways (but should be both in inclusive ways, such that 'my space is your space'). This paradoxical representation is standard fare in Derrida's approach to hospitality. He used it as a conceptual wedge to separate political constraints from ethical ones, a tactic that, he believed, reveals the possibility of 'another international law, another border politics, another humanitarian politics, indeed a humanitarian commitment that effectively operates beyond the interests of Nation-States' (1999 [1997]: 101).

The development of an international space across which Others can move, but cannot move freely (because states are sovereign, bounded, and distinguish between members and aliens), has posed complex moral and legal challenges for metropolitan political theorists since the eighteenth century. It is not surprising that Enlightenment ideologists, when they dreamed of global citizenship, would turn to hospitality in hopes of resolving new manifestations of a very old problem: how to manage welcome and trespass in ways that protect both insiders and outsiders. The rights of strangers are a principal theme, for instance, in Kant's Perpetual peace (1957 [1795]), a canonical text of European political theory. Kant believed that humans could live in societies without war, and without standing armies, if they agreed to three conditions. First, every state should have a republican constitution. Second, international law should be based on a federation of free states. Kant's third 'definitive article' is the most distinctive in its wording and justification: 'The law of world citizenship shall be limited to conditions of universal hospitality'.

Hospitality means the right of a stranger not to be treated as an enemy when he arrives in the land of another. One may refuse to receive him when this can be done without causing his destruction; but, so long as he peacefully occupies his place, one may not treat him with hostility. It is not the right to be a permanent visitor that one may demand. A special beneficent agreement would be needed in 
order to give an outsider a right to become a fellow inhabitant for a certain length of time. It is only a right of temporary sojourn, a right to associate, which all men have (1957 [1795]: 20).

Kant's reluctance to make hospitality a legal guarantee of residence suggests that he understood the ambiguity caused by the roles of host and guest in a political field where sojourners are already citizens of free and nominally equal states. He resolves this ambiguity by moving universal hospitality to the outer edges of republican order, to spaces different from those occupied by 'fellow inhabitants'. Balga Bedouin do the same by receiving guests in special areas of the house that are physically set apart and by restricting the host/guest relationship to 'three days and a third'.

What emerges clearly from these very different settings is a set of moral dilemmas that are persistent and shared, and which hospitality seems uniquely to express. The problem, for Derrida, is one of accepting Others, yet retaining the power to accept them, a stance that re-creates a sovereign space that cannot be occupied on the same terms by guest and host. For Kant, it is the problem of encouraging global movement and free association without giving travellers the right to settle in any republic as they please, preserving for them instead a small, but universal, space of protected mobility and exchange. For Balgawis, it is the problem of admitting outsiders into privileged domestic space, then letting them go, a transaction that fosters neither incorporation (where hospitality ends and membership begins) nor free movement (which would destroy the integrity of domestic space), but instead produces a zone of momentary entanglement in which friendship and violence are possible.

In all of these scenarios, the underlying problem is one of sovereignty over a space whose incompleteness, both as a physical and sovereign space, must be perpetually managed in ways that encourage interaction with outsiders. Bad guests and hosts come in many dramatic forms, but even before they drop the millstone or sever the hand that greets them, they are first of all people who refuse to accept the proper role of host or guest. This refusal is most likely to occur when guest and host cannot agree on who controls the space of interaction, who is sovereign, who belongs, and who owes or should offer respect. The inequalities of global commerce can create this disagreement, as can postcolonial immigration, or a simple lack of respect for the lesser or better man. Shifts in scale compound these disagreements and create new ones.

The development of legal fictions such as 'the citizen', an essential component of Kant's 'free republic', is perhaps the most radical generator of bad hosts and bad guests ever devised, largely because it uses the notion of equality to patch up the incompleteness of the spaces in which hospitality is performed. In a world of free republics, it is not necessary (nor is it legally permissible) for citizens to feed and shelter foreigners on their own terms - that is, with disregard for the laws of the state - and the space in which foreigners enjoy their officially guaranteed right of 'temporary sojourn' is itself located beyond domestic space, which places it beyond the realm of house, host, and guest. How does one care for people in this space? Who does so? The answers, obvious to us now, are provided by the hospitality industry (the market in hotels, restaurants, and other sites of temporary accommodation) and the government bodies that control immigration and naturalization, creating citizens, providing temporary legal rights to citizens out of place, and imprisoning, deporting, or eliminating those who cannot be given a place.

Philosophers and storytellers, who pose problems more often than they solve them, have been reluctant to sort out the details of commerce and nationalist politics as modern platforms for hospitality, perhaps because the relations between host and guest 
that prevail in these spheres are depersonalized, formulaic, monetized, and designed to insulate all parties from the risks and inconveniences of sharing. Kant understood that the 'right of temporary sojourn' required less of hosts, and more of guests, than did older models of hospitality. To avoid the bad hospitality it would engender, Kant's only advice was to keep people moving and to insist that travellers and locals not oppress each other. Derrida seems to have no fixed agenda, except to suggest that we welcome Others and accept their differences, a gesture that turns the assimilationist state into a bad host but offers no protection against bad guests. The Balga Bedouin, who would never confuse karam with the hospitality offered to tourists or the bureaucratic handling of foreigners by the state, have devised their own solution. Aptly, it requires host and guest to exit the moral space of hospitality and enter a space of identification that is even more demanding.

'After forty days', they say, 'you become one of us'.

\section{Ruins and renovations}

The effects of reconfiguring a hospitality assemblage are more immediately understood if we return to a specific case: namely to that of Dhiyab al-Adwan, who threatened to disgrace his virgin guests, and his brother, Salih, who intervened to protect them. In 1990, while doing research on Adwani history, I visited Hesban, where Dhiyab built his fortress and flour mills, circa 1777. They were in utter ruin, but still prominent on the landscape. Local families, some of them descendants of Dhiyab's slaves, had taken stones from these abandoned structures and used them to build their own houses. The big landowners in the area were from non-Adwani tribes, or from Adwani sections not descended from Dhiyab. The great shaykh's legacy, it seemed, was the story of his demise and the physical remains of the structures he had erected to defend himself and dominate the Balga.

When I returned to Hesban in 1998, I was surprised to find that the old fortress had been thoroughly renovated by Sultan Abd al-Majeed, a wealthy Adwani businessman who is also a direct lineal descendant of Salih al-Adwan, Dhiyab's rival. Sultan had bought back hundreds of stones used in local houses, landscaped the grounds with palm trees, and decorated the interior of the fortress with antiques inherited from his father, Abd al-Majeed al-Adwan, a former governor of Amman. In keeping with our theme, Governor Abd al-Majeed was killed during the Jordanian civil war of 1971. Having granted sanctuary to Palestinian guerrillas who had managed to enter his house, he was shot by Jordanian security forces, some say accidentally, others say intentionally. King Hussein, as if to compensate for this act, established close and supportive ties with the governor's son. Now Sultan, head of a family damaged by the violent encounter between state law and the laws of hospitality, has taken possession of another house destroyed by violence.

Sultan Abd al-Majeed does not live in the fortress. He hosts parties there, and these are attended mostly by his urban business associates, who marvel at the artefacts Sultan has amassed for display: an old Hashemite throne, rifles, swords, Bedouin dresses, historical photographs, coffee paraphernalia, camel saddles, and a goat-hair tent pitched in the back yard, which boasts a lush patch of green lawn, irrigated at great expense. On the far wall of the courtyard hangs an immense metal serving tray that Sultan's father used to feed meat to his guests. The residue of older hospitality assemblages is proudly recycled in Sultan's weekend resort, with implications Jordanians consider worthy of interpretation and debate. 
The Amir Hassan, brother of King Hussein, offered Sultan a medal recognizing his repairs to the fort as a contribution to Jordanian national heritage, a legacy that, under Hashemite curatorship, situates Arab hospitality in larger contexts of Hellenic, Roman, and Abrahamic civilization, all of which are evident in the ruins and cultural practices found throughout Jordan. Sultan declined the award, refusing to play host on a national scale (and protecting himself from the duties official recognition might entail). Some Adwanis accuse Sultan of engaging in conspicuous consumption and touristic display, claiming that the opulent parties he hosts have nothing to do with Jordanian heritage, or with karam of the sort his ancestors practised, and everything to do with business deals and attempts to impress his colleagues. Others contend that, for Adwani shaykhs, hospitality has always been a matter of 'intimidation and enticement', and that Sultan's fortress is an appropriate venue for both.

Sultan is not Dhiyab, nor does he make much of the connection between the fortress and its original owner; none the less, the suggestive power of older assemblages has resurfaced in Hesban. Sultan's fortress, with its links to a history of tribal and state violence, provokes ambivalent responses. What kind of sovereignty is on display there? The desire to ask this question, and the inability to answer it decisively, is perhaps the best evidence that hospitality inhabits both the ruin and its renovation.

\section{NOTES}

${ }^{1}$ Herzfeld (1987) and Friese (2009) provide critical reviews of these regional literatures.

${ }^{2}$ For an analysis of hospitality in ancient Greece, Finley's (1978) work is superb, as are Derrida's (200o) reflections on Sophocles. For discussions of Roman moral philosophy, see Goux's (2002) recent study of Seneca.

${ }^{3}$ A Google book search using the word 'hospitality' shows the concept's enduring links to religious thought. Books about the 'hospitality industry' predominate, but another large block of titles is produced by authors who write for, and as, Christians.

${ }^{4}$ This term bears the Deleuze trademark, but I use it here simply to mean a consequential arrangement of parts.

${ }^{5}$ The historical contours of 'house politics' in Jordan are examined in Shryock \& Howell (2001).

${ }^{6}$ Related accounts of the Ottoman and early Hashemite periods are available in Abu Jaber (1989), Alon (2009), and Wilson (1987).

${ }^{7}$ Appadurai's discussion of 'tournaments of value' (1986) provides a larger context in which to think about the competitive logic of feasting.

\section{REFERENCES}

Aвu Jaber, R. 1989. Pioneers over Jordan. London: I.B. Tauris.

Alon, Y. 2009. The making of Jordan. London: I.B. Tauris

Appadurai, A. 1986. Introduction. In The social life of things (ed.) A. Appadurai, 3-63. Cambridge: University Press.

Derrida, J. 1997. Politics and friendship: a discussion with Jacques Derrida (available on-line: http:// www.livingphilosophy.org/Derrida-politics-friendship.htm, accessed 11 January 2012).

1999 [1997]. Adieu - to Emmanuel Levinas (trans. P.-A. Brault \& M. Naas). Palo Alto, Calif.: Stanford University Press.

200o. Of hospitality (trans. R. Bowlby). Palo Alto, Calif.: Stanford University Press.

Finley, M. 1978. The world of Odysseus. New York: Viking.

Friese, H. 2009. The limits of hospitality. Paragraph 32, 51-68.

Goux, J.-J. 2002. Seneca against Derrida: gift and alterity. In The enigma of gift and sacrifice (eds) E. Wyschogrod, J.-J. Goux \& E. Boynton, 148-60. New York: Fordham University Press.

Herzfeld, M. 1987. 'As in your own house': hospitality, ethnography, and the stereotype of Mediterranean society. In Honor and shame and the unity of the Mediterranean (ed.) D. Gilmore, 75-89. Washington, D.C.: American Anthropological Association. 
Kant, I. 1957 [1795]. Perpetual peace (trans. L. Beck). New York: Liberal Arts Press. MAuss, M. 1967 [1925]. The gift (trans. I. Cunnison). New York: Norton.

Pitt-Rivers, J. 1977. The fate of Shechem: essays in the anthropology of the Mediterranean. Cambridge: University Press.

1992. Postscript: the place of grace in anthropology. In Honor and grace in anthropology (eds) J.G. Peristiany \& J. Pitt-Rivers, 215-46. Cambridge: University Press.

Sнrуоск, A. 1997. Nationalism and the genealogical imagination: oral history and textual authority in tribal Jordan. Berkeley: University of California Press.

2004. The new Jordanian hospitality: house, host, and guest in the culture of public display. Comparative Studies in Society and History 46, 35-62.

2008. Thinking about hospitality, with Derrida, Kant, and the Balga Bedouin. Anthropos 103, 405-21.

- \& S. Howell 2001. 'Ever a guest in our house': the Emir Abdullah, Shaykh Majid al-'Adwan, and the practice of Jordanian house politics. International Journal of Middle East Studies 33, 247-69.

Wilson, M. 1987. King Abdullah, Britain and the making of Jordan. Cambridge: University Press.

\section{Déconstruire l'hospitalité : mauvais hôtes, mauvais invités et souveraineté}

Résumé

Quand on parle d'hospitalité, que ce soit avec des Bédouins Balga en Jordanie ou avec des politologues européens, le débat s'oriente souvent vers le problème des mauvais hôtes et des mauvais invités. C'est à croire que la mauvaise hospitalité s'accumule dans les vides créés par les changements d'échelle, lorsque les maisons absorbent d'autres maisons, lorsque les États-nations et leurs citoyens se font concurrence pour contrôler les concepts et les pratiques qui définissent la maison, l'hôte et l'invité. Passant de l'histoire des Bédouins à la théorie politique métropolitaine, je montrerai ici comment les mauvais hôtes et les mauvais invités déconstruisent l'hospitalité, révélant ses composantes et leur manière de fonctionner.

Andrew Shryock is Professor of Anthropology at the University of Michigan. He studies political culture in the Middle East, Arab, and Muslim communities in North America, and new approaches to history writing. His recent books include Deep history: the architecture of past and present (University of California Press, 2011) and Islamophobia/Islamophilia: beyond the politics of enemy and friend (Indiana University Press, 2010).

Department of Anthropology, University of Michigan, Ann Arbor, MI 48104, USA. ashryock@umich.edu 